\title{
UNIVERSITY OF HOHENHEIM
}

\section{0}

Hohenheim Discussion Papers in Business, Economics and Social Sciences

\section{WASTED!}

RESOURCE RECOVERY AND WASTE MANAGEMENT IN CUBA

Michael Ahlheim

University of Hohenheim

Maike Becker

University of Hohenheim

Yeniley Allegue Losada

Universidad de La Habana

Heike Trastl

University of Hohenheim

\section{Institute of Economics}

25-2018 


\title{
Discussion Paper 25-2018
}

\section{Wasted! \\ Resource recovery and waste management in Cuba}

\author{
Michael Ahlheim, Maike Becker, Yeniley Allegue Losada, Heike Trastl
}

Download this Discussion Paper from our homepage:

https://wiso.uni-hohenheim.de/papers

ISSN 2364-2084

Die Hohenheim Discussion Papers in Business, Economics and Social Sciences dienen der schnellen Verbreitung von Forschungsarbeiten der Fakultät Wirtschafts- und Sozialwissenschaften. Die Beiträge liegen in alleiniger Verantwortung der Autoren und stellen nicht notwendigerweise die Meinung der Fakultät Wirtschafts- und Sozialwissenschaften dar.

Hohenheim Discussion Papers in Business, Economics and Social Sciences are intended to make results of the Faculty of Business, Economics and Social Sciences research available to the public in order to encourage scientific discussion and suggestions for revisions. The authors are solely responsible for the contents which do not necessarily represent the opinion of the Faculty of Business, Economics and Social Sciences. 


\title{
Wasted! \\ Resource recovery and waste management in Cuba
}

\author{
Michael Ahlheim ${ }^{1}$, Maike Becker ${ }^{2}$, Yeniley Allegue Losada ${ }^{3}$, Heike Trast| ${ }^{4}$
}

\begin{abstract}
The collection of solid waste and the recovery of recyclable material from waste belong to the many challenges Cuba has been facing over the past years. In this paper, we give a short account of the actual waste situation and analyze the causes of the obvious deficiencies of the waste sector. We conducted a small survey in Havana city in order to assess people's awareness of the garbage problem, their appraisal of the actual situation and their willingness to contribute personally to an improvement of the waste situation. Based on the insights gained from this survey and from our theoretical analysis of the Cuban waste management we develop suggestions for an improvement of the waste situation in Cuba. These suggestions take into account that the financial means available for a reform of the waste management system in Cuba are severely restricted. Therefore, our suggestions are more focused on organizational and motivational changes than on the introduction of high technology.
\end{abstract}

Keywords: Waste Management, Recycling, Incentives, Contingent Valuation, Cuba JEL Classification: H4, I31, Q53, Q28

1 Prof. Dr. Michael Ahlheim, Environmental Economics, Regulatory and Consumer Policy, Institute of Economics (520F), University of Hohenheim, 70593 Stuttgart, GERMANY, Tel.: (+49) -711-459-23596, Fax: (+49) -711459-24081; E-Mail: ahlheim@uni-hohenheim.de.

2 Maike Becker B.Sc., Environmental Economics, Regulatory and Consumer Policy, Institute of Economics (520F), University of Hohenheim, 70593 Stuttgart, GERMANY, Tel.: (+49) -711-459-22512, Fax: (+49) -711459-24081; E-Mail: maike.becker@uni-hohenheim.de

3 Prof. Dr. Yeniley Allegue Losada, Facultad de Economía, Universidad de La Habana, Calle L, No. 353 entre 21 y 23, Vedado, 10400 La Habana, Cuba, Tel.: +537 7832 8427, E-Mail: yeniley.allegue@gmail.com.

4 Heike Trastl M.Sc., Environmental Economics, Regulatory and Consumer Policy, Institute of Economics (520F), University of Hohenheim, 70593 Stuttgart, GERMANY, Tel.: (+49) -711-459-22512, Fax: (+49) -711-459-24081; E-Mail: heike.trastl@uni-hohenheim.de. 


\section{Introduction: Waste in Havana - first impressions}

Visitors to Havana are surprised to find huge heaps of garbage at many street corners not only in the residential areas outside the city but also in its Historic Centre. While for them the obvious deficiencies in garbage collection constitute only a minor aesthetical impairment of an otherwise beautiful city, things are much more serious for the permanent residents of Havana. Waste is accumulating in most streets over two weeks and more before it is collected by the Municipal Communal Services Administration, the so-called "communales". This leads to major sanitary problems since various kinds of animals like rats or mosquitos settle down in the waste. In the rainy seasons contaminated water is leaking from the waste heaps. As a result, the health of the population is impaired by contagious diseases caused by the deficient waste management (cf. Louro 2013).

According to the administration responsible for garbage collection, they are required to collect the garbage in residential areas at least every 72 hours. In reality, this often happens only every fortnight or even more rarely. The reasons for that are manifold. There are technical reasons like broken waste trucks, which are not repaired in time, and destroyed garbage containers, which cannot be moved or lifted off the ground in order to be emptied into the garbage trucks (cf. Alberty 2014). However, there are also social or psychological reasons, which are suspected to be due to the mentality of the residents on the one hand and of the public servants of the communales on the other. Especially in the poorer and more run-down areas of Havana, residents do not really seem to care for the garbage situation. Additionally, the current situation is influenced by elements of corruption, demoralization and lack of control among communal workers. This has a direct impact on the waste management but also on the hygienic-epidemiological situation of the capital (cf. Alberty 2014, Louro 2013). It is neither clear if the population is aware of the garbage problem nor what people's attitude towards this problem is. Therefore, we conducted a small face-to-face survey in the city of Havana in order to highlight these issues and to identify possible solutions to the garbage collection problem, which might be based on people's opinions and their willingness to cooperate with the city administration in order to improve the garbage situation.

Garbage collection is not the only waste problem in Cuba. The recovery of recyclable materials from the collected solid waste is practiced in Cuba, but the treatment and final disposal of the rest of the solid waste is inappropriate and puts the environment in the neighborhood of the landfills and the health of the population at risk (cf. Lloréns et al. 2008 and 2009).

The paper is organized as follows. In the next section, we will assess the garbage situation in Havana from the residents' perspective using a small citizen survey. We will first explain the details of our survey and then present its results. In section 3 we will give a comprehensive account of the actual garbage collection and treatment practice in Cuba, while in section 4 we will develop some recommendations for an improvement of the waste management system without prohibitively high costs. Section 5 contains some concluding remarks. 


\section{A Contingent Valuation survey in Havana - What do Cuban people think?}

In March 2018 we conducted a small-scale face-to-face survey in Havana in order to gain better insights into people's awareness of the garbage problem and their opinions regarding the causes of this problem and possibilities to cope with it in the future. We also wanted to find out to which extent they would be willing to assume responsibility personally by contributing financially to an improvement of the garbage management in Havana.

\section{$2.1 \quad$ The survey}

This survey followed, in principle, the so-called Contingent Valuation Method (CVM) for the assessment of the social benefits accruing from public projects for which no market prices exist (cf. e.g. Atkinson and Mourato 2008, Carson and Hanemann 2005 or Bateman et al. 2002). Public projects causing environmental effects create different kinds of benefits. In the case of an improved waste collection system people's personal situation would improve e.g. because their neighborhood would be enhanced under hygienic and aesthetical aspects. This is the so-called use value of a public project (cf. Nunes 2002, p. 4), i.e. the value that accrues to people on site who receive an immediate and personal benefit from the project in question. Beyond these benefits, people might appreciate the idea that also future generations can enjoy the improved technical and logistical infrastructure for waste collection that would be built up today in the course of such a project. These benefits accruing to people living today from the knowledge that also the living conditions of future generations would be enhanced by the public project are called its bequest value. Bequest values belong to the category of the so-called nonuse values (cf. Bateman et al. 2002) created by a public project. The CVM aims at the assessment of the total value of public projects, which consists of both, use and nonuse values.

The questionnaire we used in our survey consisted of three main parts. In the first part, we asked people about their own experience with and their own view of the garbage collection problem in Havana. We wanted to know if they notice the garbage heaps in the streets and if they know about the environmental and health problems arising from them. We inquired also into their opinions regarding the causes of the actual garbage situation in most housing areas and we asked who they think should be held responsible for this situation.

In the second part, we wanted to find out if they were willing to contribute personally to improve the situation by paying a newly introduced monthly garbage fee. The money collected through this new fee would be used to finance an improved garbage management system, which in our questionnaire was called WaMaHav ("Improved Waste Management system for Havana"). After a detailed description of this hypothetical project, we asked respondents if they were, in principle, willing to support the implementation of such a waste management system by paying a new garbage fee. To those who answered "yes" we presented a so-called Payment Card with 15 different payment intervals, ranging from "0 CUP", " 1 to 5 CUP", " 6 to 15 CUP" etc. up to "More than 320 CUP". Then we asked them to tick the interval with the maximum amount of the fee, which they would be willing to pay in order to get WaMaHav realized.

In CVM studies, the amount an individual is willing to pay for the realization of a public project is interpreted as the monetary expression of the utility or benefits the individual expects from 
that project. The higher the willingness to pay (WTP) of an individual for a public project is, the higher are the benefits expected. The sum of the WTP amounts of all individuals affected by a public project is interpreted as the total social value of that project. In order to assess this social value CVM interviews are conducted with a representative sample of all individuals affected. The mean or average WTP of this sample is then multiplied by the number of all people affected in order to assess the social value. Obviously, this procedure leads to useful results only if the mean WTP of the sample equals the mean WTP of the target population, i.e. if the sample is representative. In our case, we conducted street intercept interviews with only 43 persons, so we could not hope for more than a rather superficial snapshot of Havana residents' opinions as well as their WTP. A more precise picture could be gained only from a much larger study with at least 1,000 completed interviews (cf. Arrow et al. 1993). In the third part of our questionnaire, we asked respondents about their personal socio-demographic data like e.g. gender, age, income, educational level and their job situation.

\subsection{Survey results}

All of our respondents were citizens of Havana, $72 \%$ of them were even born there. They came from all 15 districts of Havana, but most of them were from Centro Habana (32\%) or Habana Vieja (13\%). The average age was 45 years, $61 \%$ of the respondents were married or divorced and $58 \%$ had children. About $28 \%$ of the respondents were government employees, while $31 \%$ were self-employed. About $13 \%$ were students or trainees and $10 \%$ were retired.

All respondents considered garbage collection services in Havana insufficient and they were also concerned about negative consequences for their health and for the environment in general. When asked about the three most important environmental consequences of the garbage collection problem, $79 \%$ of our respondents chose at least one of the three kinds of water pollution offered for selection in our questionnaire (surface water, ground water, Havana Bay), 58\% selected the "Impairment of the beauty of the city" and 51\% stated that the garbage pollutes the air. We then wanted to know which health problems they attributed to the insufficient garbage collection practice. From the catalogue we offered them, $56 \%$ of the respondents chose "Problems with the respiratory system", 47\% named health problems caused by contaminated tap water in households and $40 \%$ held the insufficient waste collection practice responsible for skin problems.

After that we wanted to know (using a five-point Likkert scale from "not serious at all" to "very serious") how serious respondents considered a number of different consequences of the careless waste collection practice in Havana. Here $97.6 \%$ of the respondents found the fact that "Waste in the streets as habitat and nutrition for animals like rats, cockroaches, flies and mosquitos" was either "serious" (11.9\%), "quite serious" (11.9\%) or "very serious" (76.2\%). Similarly, high scored the "Smell from the waste deposition in the streets", which $97.6 \%$ of our respondents found either "serious" (9.5\%), "quite serious" (26.2\%) or "very serious" (61.9\%). Further, the "Sight of waste in the streets" appeared to $95.3 \%$ of respondents either "serious" (21.4\%), "quite serious" (19.1\%) or "very serious" (54.8\%). While people are obviously worried most about the animals living in the garbage heaps and, probably, the threat they pose to human health, also aesthetic values like the smell or sight of garbage seem to bother them considerably. All these effects of the garbage problem lead to direct losses of people's 
wellbeing in the sense that they are immediately affected by them. It turns out that, in addition to these direct effects, our respondents were also worried about more general effects like groundwater pollution (70.7\% find it either "serious", "quite serious" or "very serious"), surface water pollution (78.1\%), soil pollution (66.7\%) or the effects on tourism (75.6\%). All of these effects do not necessarily affect their own wellbeing. This shows that at least the members of our survey sample were concerned not only about their own wellbeing but also about threats to the wellbeing of society as a whole. Interestingly, nearly $50 \%$ of our respondents did not believe that "Other people living in Havana are aware of the problems accruing from inefficient waste management", while nearly $100 \%$ of them said that they themselves were concerned. This asymmetric perception of their own awareness of the garbage problem on the one hand and the awareness of others on the other hand is rather surprising and hints already at a certain degree of skepticism regarding the sense of responsibility of other members of society.

When asked what the main causes of the ineffectiveness of the garbage management in Havana are, $63 \%$ of our respondents found that "There are not enough garbage containers in the streets", 52\% thought that "There are not enough trucks for the transportation of garbage" and $49 \%$ of the respondents held the "Inefficiency of administration" responsible for the problem. It was amazing that $80 \%$ of the respondents answered "no" to the question, if corruption could be a cause of the garbage problem, while in personal discussions people often pointed at exactly this possibility when asked. Here we might have a typical case of socially or politically desirable responding, where respondents do not state their true opinion but give answers, which they think are "politically correct". It was also surprising that more than $90 \%$ of our respondents stated that the "Lack of social responsibility of people" was responsible for the garbage situation in Havana. This result corresponds closely with our previous finding that our respondents did not trust in their fellow citizens' awareness and correct assessment of the garbage problem.

Of course, people in Havana would like to have a much better garbage collection service than they have today. When asked "How often do you think garbage should be collected in Havana?", 56\% of the respondents answered "Every day". More than 33\% wanted their waste to be collected even twice a day. Obviously, people's wishes are far from reality here. When asked which policy measure they would recommend to improve the actual situation, $69 \%$ of the respondents suggested to install more trash bins in the streets and to provide new containers for household waste (also 69\%), while 58\% suggested to implement a monitoring system for the garbage trucks to make sure that they really service the whole area for which they are responsible. Interestingly, $76 \%$ of our respondents wished a better "Education of children in school on the topic". This, again, corresponds very nicely with our previous finding that people put the blame for the garbage problem on the lack of responsible behavior of their fellow citizens. Obviously, the "human factor" is considered one of the major causes of the garbage problems.

After having obtained this rather comprehensive impression of people's attitude towards the garbage situation in Havana we wanted to know if they were willing to contribute personally to an improvement of the situation. In our questionnaire, we presented a waste management scenario to them describing the above-mentioned WaMaHav system: 
"Scientists have suggested a public program for an improvement of the garbage situation in Havana. This program is called "Improved Waste Management of Havana" (WaMaHav). It comprises among others policy measures like the installation of more waste bins in all districts of the city, more trucks for waste collection, strict monitoring of garbage truck drivers to force them to do their duty, investment in new containers for household garbage and environmental education. Further, they want to ensure that garbage is collected at least every third day in all districts in the city."

Then we asked if, in principle, they would support this program if they had to pay a new garbage fee in order to get it realized. Surprisingly, $92.5 \%$ of our respondents answered this question in the affirmative. This proves that people in Havana are, indeed, serious about the necessity to change the existing practice of garbage collection, at least as far as our survey sample is concerned. In the next step, we wanted to obtain a quantitative impression of their readiness to support a change in the garbage collection practice by asking the following question:

"Considering the benefits of this program for you personally and for all people living in Havana we would like to ask you to mark in the following list which amount of a garbage fee your household would be willing to accept at maximum in order to get the WaMaHav project realized: ...

(It follows a Payment Card with 15 different payment intervals, ranging from "O CUP", "1 to 5 CUP", "6 to 15 CUP" etc. up to "More than 320 CUP")"

From the amounts marked in the payment card we computed a mean willingness to pay (WTP) for WaMaHav of 24 CUP per month, which corresponds to nearly 1 Euro per month. This amounts to roughly $1 \%$ of the average income of our sample members.

Summing up, our results show that among the population of Havana there is a high degree of awareness of the garbage collection problem, the threats it poses to the environment in general as well as to human health. We also found that people are ready to contribute personally and financially to an improvement of the garbage situation in Havana. This emphasizes that the topic of our research here is, indeed, relevant for the population of Havana. In the next section we will analyze in detail how the waste management in Havana and in Cuba in general is organized and where sources of inefficiency might be located.

\section{The waste collection and management system in Cuba}

\subsection{The organization of waste management in Cuba}

The organization of waste management in Cuba is rather complex. Its main structure is shown in the diagram in fig. 1 . Our analysis here will be oriented towards this diagram. Total waste in Cuba consists of waste from public enterprises in the production and service sector and of 
private waste coming from households and from private enterprises, e.g. restaurants, small hostels and various service units. Private waste can be disaggregated into residual waste (RW) and recyclable material (RM). Private households dispose of their waste into public garbage containers placed in their neighborhood. Typically, they do not separate their waste into a residual waste fraction and a recyclable material fraction. Nevertheless, some private households do this and bring their recyclable material directly to so-called Buyback Centers ("casas de compra") 5 where they get a small amount of money for it. The collection of the residual waste is organized by the Municipal Communal Services Administration (MCSA) ${ }^{6}$, also called the communales. According to the law, their trucks are supposed to collect the waste every 72 hours or even more frequently and bring it directly to one of the landfills. In practice, the waste removal service does not adhere to this time schedule in many parts of the city. The reasons for that are manifold and will be discussed below in detail.

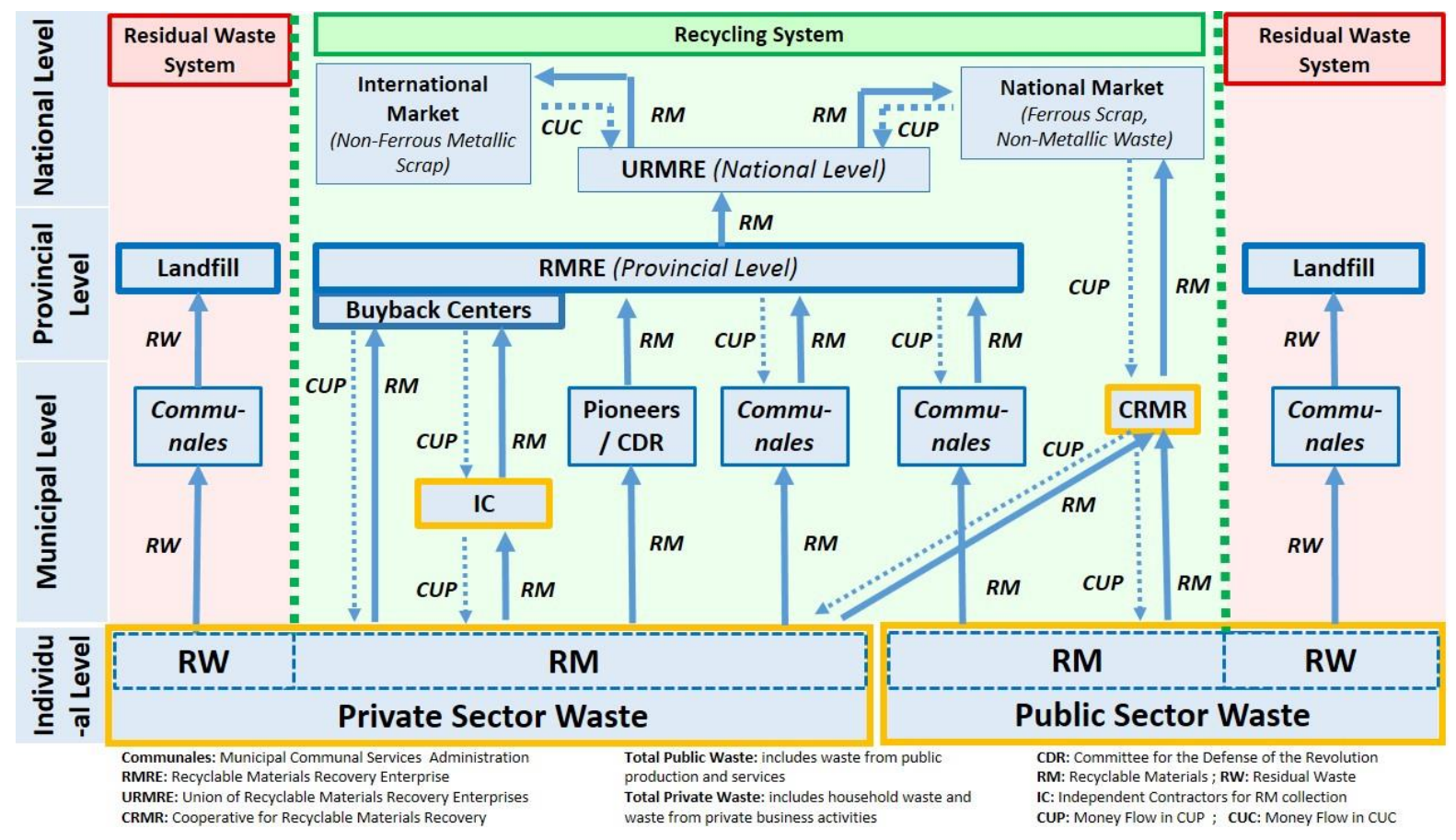

- Fig. 1: The Waste Management System of Cuba -

Though most private households as well as private enterprises do not separate their garbage actively, some of the recyclable materials are still recovered from their garbage by

\footnotetext{
5 Casas de Compra (Buyback Centers): A national network of small establishments located in urban areas that buy directly raw materials from the citizens and other organizations.

${ }^{6}$ Dirección Municipal de Servicios Comunales (Municipal Communal Services Administration - communales): This is a government institution responsible for the collection and disposal of solid waste (either to landfills or to the Recyclable Material Recovery Enterprises). Besides their primary function, the communales bear also the responsibility for sweeping the streets, sidewalks and other common areas as well as for environmental sanitation.
} 
Independent Contractors for Recyclable Material Collection (IC) ${ }^{7}$ on the one hand and by Cooperatives for Recyclable Material Recovery (CRMR) ${ }^{8}$ on the other. These Cooperatives are usually spin-offs of public enterprises and are organized like private firms. Like the ICs they depend on making profits of their own as an income because they are not paid by government. ICs as well as CRMRs pay private households and enterprises for the recyclable material they collect from them, even though these are only small amounts of money. The Independent Contractors bring the collected material together with other recyclable materials they collect directly from public waste containers, landfills etc. to the Buyback Centers where they get paid for it. The Buyback Centers belong to the Recyclable Material Recovery Enterprises at a provincial level (RMRE) ${ }^{9}$, where the valuable material is recycled and then sold to the national and international industry. The Cooperatives sell the recyclable material directly to the national industry.

There are also recyclable material collection activities organized by the young Pioneers ("Pioneros") 10 and the so-called Committees for the Defence of the Revolution ("Comités de Defensa de la Revolución" - CDR) ${ }^{11}$. Differently from the ICs these organizations collect recyclable material without paying for it. The communales who already collect the residual waste are also involved in the collection of recyclable materials from private households and enterprise and they do not pay for them, too. The Pioneers, the Committees and the communales deliver the recyclable materials they collect directly to the provincial RMREs, where from this group only the communales get paid for these materials.

The waste produced by the public sector can also be subdivided into recyclable material and residual waste. Public enterprises are obliged by law to separate their waste into recyclable material and residual waste. The residual waste is collected by the communales and delivered directly to one of the landfills. No money payments are involved here. Part of the recyclable material is collected by the Cooperatives for Recyclable Material Recovery who pay for these materials. As explained above, they sell the recyclable materials directly to the national industry. The other part of the recyclable material is also collected by the communales and then sold to the RMREs.

${ }^{7}$ Trabajadores por cuenta propia (Independent Contractors for Recyclable Material Collection - IC): Independent workers who collect and pick up recyclable material from private garbage and sell it to the Buyback Centers. They are not subordinated to any firm or organization.

${ }^{8}$ Cooperativas de Recuperación de Materias Primas (Cooperatives for Recyclable Material Recovery - CRMR): Independent Cooperatives, which collect recyclable material from private and public waste and sell it to the national industry.

9 Empresa Provincial de Recuperación de Materias Primas (Recyclable Material Recovery Enterprise at the provincial level - RMRE): Government enterprise responsible for recycling at the provincial level. It belongs to the Union of Recyclable Materials Recovery Enterprises (national level).

10 Pioneros (Pioneers): It refers to Cuban children and adolescents (between five and fifteen years of age) who are part of the "José Martí" Pioneer Organization. This organization carries out sports, cultural, recreational activities and also social responsibility activities like collecting garbage.

11 Comités de Defensa de la Revolución (Committees for the Defense of the Revolution - CDR): Non-governmental organization composed of the population older than 14 years. It is spread all over the country, both in rural and urban areas. This mass organization carries out different socially supportive activities such as volunteer work, health promotion (vaccinations, blood donations, etc.), protection of the environment and also the collection of recyclable materials. 
In principle, this procedure is rather similar for all 15 provinces of Cuba. Each provincial RMREs forwards its recyclable material to the Union of Recyclable Materials Recovery Enterprises (URMRE) ${ }^{12}$, which works at the national level. The URMRE sells the ferrous part of the metallic waste as well as the non-metallic waste to the national industry. The non-ferrous metallic scrap is sold in the national and also in the international markets, where it is paid for in convertible currency which then is converted into CUC. Applying the prices of the international market of recycled waste, the combination of the import substitution and/or the export of the non-ferrous metallic scrap represent more than 200 million dollars of savings to the national economy (cf. Tamayo 2017).

\subsection{The performance of the waste management in Cuba}

There are two main kinds of deficiencies of the Cuban waste management system, which are interrelated with each other. As described in detail in sections 1 and 2 of this paper, the private waste is collected not frequently enough so that heaps of garbage and overflowing garbage containers mark the picture of many streets in Havana and in other cities in Cuba. The uncollected waste provides habitat for many kinds of animals like rats, cockroaches, mosquitos and other species, which pose a potential threat to human health. Another consequence of the sloppy garbage collection and separation practice is that a much lower fraction of the waste is recycled in Cuba than would be possible. This causes an enormous loss of valuable scrap and, accordingly, of money since more raw materials have to be imported and less raw material can be exported than under a functioning and efficient waste separation and recycling regime.

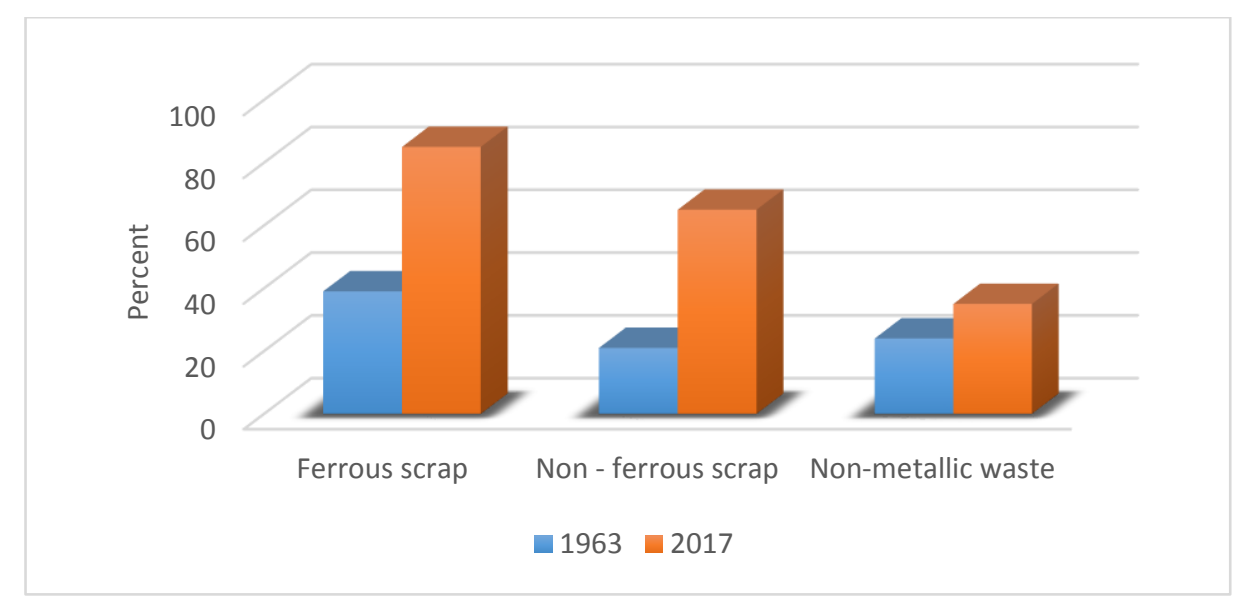

- Fig. 2: The three main fractions of recycled raw material in Cuba -

In Cuba, about 400 thousand tons of waste are recycled every year (cf. Cubadebate 2013). Comparing the recycling rates of 1963 and 2017 (cf. fig. 2), one finds that there has been a

\footnotetext{
12 Unión de Empresas de Recuperación de Materias Primas (Union of Recyclable Materials Recovery Enterprises - URMRE): This government institution is responsible for the collection, processing and sale of recyclable waste generated in the private and state sectors in the areas of production and services.
} 
considerable growth in the recycling of metallic scrap (ferrous and non-ferrous) while the recycling of non-metallic waste is still in its infancy ${ }^{13}$ (cf. Jank 2018).

The reason for that is that in Cuba even today a suitable technology for the recycling of many kinds of non-metallic waste is not available or not applicable. Also for metallic waste, especially non-ferrous scrap, an increase in the recycling rate would be desirable. In the next subsection, we will analyze the main causes of these deficiencies of the Cuban waste management.

\subsection{Causes and sources of failure in Cuban waste management}

The analysis in this section will be based on ffig. 1 again. It has been mentioned before that the collection of private residual waste by the trucks of the communales is rather erratic and unreliable. Residents of certain parts of Havana often have to wait for more than two weeks until their garbage is collected. Reasons for that are, among others, technical deficiencies of many garbage trucks and a much too small number of trucks as well as of drivers, but also the poor work ethic and the low skills of the garbage workers. One consequence of the infrequent garbage collection is that the containers are overflowing so that litter is spread on the ground around the containers. When the collection trucks eventually arrive, the drivers typically do not care to collect the litter around the containers and to clean up the street. For that task, special units of garbage workers are responsible but also they mostly do a rather sloppy job. When the containers are broken, which is often the case, part of the garbage drops in the street where it then rests until it is blown away by the wind or washed away by the rain. This, again, is a result of the lack of work morale of the garbage workers, but also the residents have to be blamed for disposing of their garbage carelessly in the street when the containers are already full. In our survey $90 \%$ of respondents stated that a "Lack of social responsibility of people" is to be blamed for the garbage situation in Havana, as already mentioned in section 2 above and $50 \%$ did not believe that "Other people living in Havana are aware of the problems accruing from inefficient waste management". This shows that even Havana residents themselves hold their own peer group responsible (in parts) for the garbage problem. Summing up, regarding the insufficient quality of residual waste collection in Havana we have identified two main causes, technical problems with garbage trucks and containers on the one hand and a lack of motivation of residents as well as of garbage collectors to engage personally in a cleaner and more efficient waste collection management on the other.

In principle, these causes are also responsible for the insufficient recovery of recyclable material from private waste, since recyclable material is part of the total private waste. Differently from residual waste, there are material incentives for extracting recyclable material from private garbage and for passing it on to the before-mentioned Buyback Centers. This can be done by private households directly. When they bring certain kinds of recyclable material like e.g. tin cans or glass bottles to the Buyback Centers, they are paid a small price for that like 8 CUP per kg of tin cans or 2.5 CUP for an empty rum bottle (for more price examples see Appendix). Another possibility is that the already mentioned Independent Contractors for Recyclable Material Collection collect the recyclable material from private households and private enterprises like restaurants or hostels and bring it to the Buyback

13 Recycled waste is classified into ferrous, non-ferrous scrap (copper, bronze, stainless steel, lead, aluminum) and non-metallic waste (glass, paper, cardboard, plastic, textiles). 
Centers. The ICs pay households for the recyclable material an amount, that is even smaller than the price paid by the Buyback Centers, but the advantage for households is that they do not have to pass by the centers themselves. Further, young Pioneers as well as the Committees for the Defense of the Revolution organize campaigns where they separate and collect recyclable material at the private household and business level, where it is then picked up by the Recyclable Material Recovery Enterprises. No money payments are involved here. Recyclable material from private units is also collected by the communales. They also do not pay the private units but, differently from the Pioneers and the CDRs, they sell the recyclable material to the RMREs.

This shows that in some of the transactions regarding the collection of recyclable material money payments are involved. One might expect that these payments trigger an efficient management of the recyclable private waste. Unfortunately, this is not the case. In reality, a considerable part of the recyclable material contained in private waste remains unrecovered. The main reasons for that lie in the extremely low prices that are paid by the RMREs for recyclable material (cf. Appendix). These prices are administered prices and not market prices. Therefore, they do not indicate real scarcities of materials. The prices paid at every stage of this waste "supply chain" are much too low to set sufficient incentives to the agents involved in that chain. Differently from the Independent Contractors and the Cooperatives whose managers live off the profits they make, the Buyback Centers and the communales are nonprofit government institutions so that their managers and workers do not benefit personally from the profits made by their organization. Therefore, profits do not set personal incentives to motivate them.

Looking at the public enterprises, these are obliged to separate their waste and to forward the recyclable material either to the communales or to the Cooperatives. They are paid only for the material they pass on to the CRMRs, but not for the material collected by the communales. On which basis they decide how much of their recyclable material they sell to the CRMRs and how much they give without being paid to the communales is not clear. If they decided on the basis of prices and profits only, they would sell all of their recyclable material to the Cooperatives, which is not the case in reality. So, again we see that the price system has no sufficient allocative impact on this sector.

Summing up, since the prices that are paid within the waste collection and recycling system of Cuba are no market prices they do not indicate the true scarcity of certain waste components and they do not set incentives for the decision makers in that system to strive for efficiency.

\section{How to do better - An incentive-based approach}

Especially in the case of private households and enterprises, the Cuban waste management system fails to ensure a halfway regular collection of garbage and with that a halfway acceptable condition of the streets under hygienic and aesthetic aspects. Further, the actual organization of the waste management does not lead to a satisfactory degree of recycling and resource recovery from waste though this would be highly desirable, especially for a country like Cuba which has to import much of the raw materials it needs for its production industry. 
When reflecting upon possibilities to improve this situation many things come to one's mind which in the end turn out not to be realistic in the case of Cuba. It would be desirable to have modern waste collection trucks which have a higher loading capacity and which break down less frequently than the trucks used now in Cuba. It would also be nice to have them equipped with GPS chips so that they can be kept under permanent surveillance and called back in case they leave their prescribed route. Substituting the present garbage containers by new ones would definitely be helpful and renewing and enhancing the whole recycling industry by modern industrial recycling plants would mean a great leap forward for recycling in Cuba. Unfortunately, this kind of suggestion is not helpful in the case of Cuba since there is not enough capital available for the realization of such ideas. Therefore, we want to focus our attention in this section on possibilities to improve the efficiency of the waste management system without costly investments. This leads us directly to considerations regarding the implementation of an enhanced system of incentives for people at all stages of the waste collection and recycling process to make them strive for more efficiency and better results.

\subsection{Incentives to comply - A short overview}

While Cuban waste management is impaired by a lack of capital, the lack of positive motivation and the non-cooperative behavior of residents as well as of waste workers are also responsible to a large extent for the desolate state of the Cuban waste management. People, no matter if workers or private citizens, could contribute in many different ways to an improvement of the garbage situation also without new technical equipment. Garbage workers like the drivers of garbage collection trucks or the members of the street-cleaning service could simply stick to their stipulated working schedules in their everyday practice and fulfil their duties as thoroughly as possible with the technical equipment at hand. This would mean more working effort for them and maybe even longer working hours. The question arises how they could be motivated to take this trouble or, conversely, why they do not do it at present. Private households could show more discipline in dealing with their personal garbage. They could separate it into residual waste and recyclable material already at the household level and dump it into separate waste containers. Of course, this would have to be organized by somebody, e.g. by the neighborhood Committees for the Defense of the Revolution which are located in every housing area and in the large housing compounds. Households could refrain from dumping their garbage in the street when the containers are already overflowing and call the communales to remove the garbage, instead. They could also bring the recyclable material components of their garbage personally to the Buyback Centers if the communales fail to collect them. Again, these improvements would require additional efforts by households and the same questions arise as before: Why have they not done these things already in the past? How can they be motivated to do them in the future? Similar questions could be asked regarding all other agents involved in the garbage management of Cuba.

An obvious answer to these questions is that we are dealing with a typical public good problem here. A cleaner Havana and a higher recycling rate could be enjoyed by all citizens the same, no matter if they personally contributed to reaching these goals or not. Therefore, the optimal strategy for the individual citizen or worker is "free riding", i.e. making no personal efforts to improve the waste situation and wait for others to do this. This strategy is optimal for the typical homo oeconomicus but, as is well known and as behavioral economics theory tells us, there, in principle, are good reasons for individuals to contribute voluntarily to the provision 
of a public good if there are other incentives to do so than the consumption of the public good alone. We will briefly review the different kinds of incentives that might be effective here. In the respective literature, two main categories of incentives or motivations are discussed, namely extrinsic and intrinsic incentives (cf. e.g. Bénabou and Tirole 2003, Osterloh and Frey 2000). Sometimes as a third category "reputational incentives" (cf. e.g. Bénabou and Tirole 2006 or Ariely et al. 2009) are mentioned, though these are often subsumed under the broader categories of extrinsic and intrinsic incentives, too. We will briefly discuss the different kinds of incentives with respect to their usefulness for increasing people's readiness to contribute voluntarily to an improvement of the waste situation in Cuba.

\section{Extrinsic incentives}

There are various different forms of extrinsic incentives or motives to contribute personally to the provision of a public good or to do "something good" in general. Most common are material incentives and, especially, monetary incentives like subsidies, tax reductions or premiums paid for doing something good for society as a whole (like contributing to the provision of a public good). Material incentives are also effective on an individual level where reciprocity effects play an important role (cf. e.g. Ahlheim et al. 2013). Non-monetary material incentives could be in-kind presents like free tickets for a football game or for the opera or a case of champagne etc. Non-material extrinsic incentives to do good deeds are e.g. honorary titles, awards, medals, priority seating at official receptions, public praise by politicians or by the media etc. Also suitable nudges (cf. Sunstein and Thaler 2008) like footprints painted on the pavement which lead to a waste bin can motivate people to pro-social behavior. An important and highly effective form of non-material extrinsic incentives is the compliance with social norms in order to enhance one's social standing and reputation, thereby increasing one's social capital (cf. Coleman 1990). Complying with the requirements of social norms in order to enhance one's social standing is typically triggered by the so-called "image motivation" or "signaling motivation" for pro-social behavior (cf. Ariely et al. 2009, p. 544). This refers to "an individual's tendency to be motivated partly by others' perceptions" and the "desire to be liked and respected by others and by one's self" (cf. Ariely et al. 2009, p. 544). Doing good deeds in order to impress others and the search for social approval are parts of a person's impression management which can be described as "the process by which individuals attempt to control the impressions others form of them" (cf. Leary and Kowalski 1990, p. 34). Complying with generally accepted social norms helps also to avoid being punished by one's peer group or by society as a whole for betraying the common values and believes of this group. The threat of being shamed in public or in front of a group is especially successful as an extrinsic motivator when the monitoring of people's behavior (e.g. by neighbors, colleagues, family, media etc.) is highly effective. This discussion shows that external incentives work according to the sticks-and-carrots principle by setting positive incentives through (material or non-material) rewards on the one hand and negative incentives by the threat of social punishment on the other.

\section{Intrinsic incentives}

Typical intrinsic incentives arise from the value of a good deed per se without any reference to the perception of one's deed by others and by their reaction (reward or punishment) to it. In this case, a good deed is done for its own sake and not for the approval by others. Intrinsic incentives can be provided by altruistic, pro-social, pro-environmental or otherwise idealistic 
preferences, which make this kind of behavior more attractive without an external impulse. Altruistic preferences can be "purely altruistic" in the sense that other people's wellbeing or the wellbeing of society as a whole is important for the respective individual. Preferences can be also "impurely altruistic" in the sense of Andreoni (1989, p. 1451), whenever good deeds are done because they cause a feeling of "warm glow of giving" (cf. Andreoni 1990) for the respective individual, though she does not care at all for the wellbeing of others. In this case doing good deeds is also an instrument of enhancing one's self-image and enjoying the result, i.e. enjoying the feeling of being a good person or a good citizen. Obviously, this mechanism depends on the existence of an ideal self-image or an ideal identity, which people want to resemble as closely as possible. Therefore, this kind of incentive can be viewed as part of a person's identity management, i.e. her trying to act according to her own ideal identity (cf. Bénabou and Tirole 2011 or Akerlof and Kranton 2000). In psychology, there are various different concepts of identity and of how it is formed. Following Akerlof's and Kranton's approach identity or "a person's sense of self" (Akerlof and Kranton 2000, p. 715) depends among other things on her socio-economic characteristics (like e.g. being a woman, belonging to the working class, being a member of a Christian church or the Communist Party or an environmental group etc.) and the behavioral expectations that are connected with these characteristics by society and by oneself. As member of a Christian church, you should behave according to the ideals of the church, e.g. by following the Ten Commandments. If you violate one of them and others observe this they will react to your wrong behavior and punish you in one way or the other (e.g. by excluding you from their community). This is also the case with violating social norms in general, but identity economics according to Akerlof and Kranton points to an additional effect: Even if nobody notices your misbehavior, you will have a bad conscience because you know that your behavior contradicts your personal convictions and disappoints the expectations you place in yourself. "Violating the prescriptions evokes anxiety and discomfort in oneself and in others", as Akerlof and Kranton (2000, p. 716/17) put it. Therefore, the expectations that a person as well as her peer group or as society as a whole connects with her socio-demographic characteristics has an important influence on her behavior even without external punishment or reward. This effect offers another possibility to change people's behavior towards more pro-social actions by adjusting the expectations or "prescriptions" (Akerlof and Kranton 2000, p. 719) connected with people's social identity appropriately.

One of the advantages of intrinsic over extrinsic motivation is that intrinsic motivation does not require any external monitoring or administration like e.g. tax privileges or payments of premiums or subsidies do. Therefore, intrinsic incentives seem to be superior to extrinsic incentives under the aspect of minimizing transaction costs. Before intrinsic incentives can become effective, the appropriate social norms ("Waste separation is important for our country, therefore all good citizens should do it") or social identities ("A good Cuban communist should defend the achievements of the great Cuban Revolution by separating waste in order to save raw materials and increase the recycling rate of our country") have to be created and implanted in the thinking of people. This takes much more time than the imposition of a new tax or fee or the introduction of new subsidies and, of course, the effect of new social norms is not certain ex ante. Therefore, a combination of extrinsic and intrinsic incentives seems to be advisable for a successful employment of this instrument in practical policy. 


\section{Interaction effects}

There is a large body of literature on the possible interaction between intrinsic and extrinsic incentives. Most of this literature shows, based on lab experiments, that the introduction of extrinsic material incentives like the payment of premiums, granting tax privileges or subsidies etc. can diminish or even eliminate intrinsic motivations for good deeds or for pro-social behavior (cf. e.g. Lepper et al. 1982, Frey 1994, Fehr and Falk 1999, Fehr and Schmidt 2000, Frey and Jegen 2001, Bénabou and Tirole 2003 and 2006). This is known as the crowding-out effect or "overjustification effect" (Bénabou and Tirole 2006, p. 1654) of extrinsic incentives on intrinsic incentives. If one feels good because one voluntarily separates one's own garbage in order to contribute to resource saving for the country (or for the world), this good feeling is impaired if garbage separation suddenly becomes mandatory by law and trespassing of this law is punished, or if government suddenly introduces a fee on unseparated garbage or pays a premium for people who separate their garbage. In these cases the material reward for complying with the idealistic goal of resource saving devaluates one's voluntary efforts morally and, thereby, decreases the intrinsic motivation for these efforts. It undermines one's intention to enhance one's self-image or one's warm glow-feelings as well as the goal of enhancing one's reputation in the eyes of others, because now they might think that one is doing the good deed only because of the money. The extrinsic incentive might even reverse one's good intentions by triggering psychological reactance effects (cf. e.g. Hong and Faedda 1996 or Steindl et al. 2015).

Experiments have also shown that the crowding-out effect of introducing material incentives is often not reversible. If the intrinsic motivation has been crowded-out by extrinsic material incentives and if these extrinsic incentives are later abolished, the intrinsic motivation does often not return, at least not with the initial intensity (cf. Gneezy et al. 2011). Consequently, government should be very careful with introducing extrinsic incentives for pro-social behavior like garbage separation because this might reduce the intrinsic motivation of people to comply voluntarily with the overall ideal of resource saving and having a clean city. Once the extrinsic incentive has been introduced, there will be no way back to regain the initial level of intrinsic motivation of people. Therefore, before introducing new extrinsic incentives government should always check for the existence of intrinsic motivations in the respective field.

\subsection{Improving the Cuban waste management system}

The two main goals of reforming the Cuban waste management would be, firstly, to provide a more reliable and effective waste collection service and, secondly, to realize a higher rate of recycling and resource recovery from waste. In this section, we will consider practical possibilities to realize these two goals.

The first thing that comes to one's mind when looking at the Cuban waste management system as illustrated in fig. 1 is that it is rather complicated, if not confusing. Too many institutions are involved, responsibilities are not clear and there are many duplications of tasks. Therefore, its organizational structure should be simplified fundamentally in order to make it more efficient and to implement a consistent incentive system to trigger pro-social behavior in the whole waste management sector. Simplification of the organizational structure requires a higher degree of specialization on the side of those institutions who are responsible for the collection and further treatment of residual waste RW as well as of 
recyclable materials RM. As can be seen from fig. 1 , the collection of residual waste from the private as well as from the public sector lies in the responsibility of the communales. Although they are obviously doing a very poor job in RW collection alone, they are also involved in collecting RM from the public as well as the private sector and forwarding it to the recycling industry RMRE. Their performance in the RM business is also poor since they have no incentives whatsoever to do better. There are no monetary rewards for the workers of the communales for their work besides their rather low fixed salaries. Though the employees of the communales are also paid small premiums on top of their base salaries as incentives if they show extra work effort on their job, these payments are rather low. If the communales as firms collect recyclable material from private and/or public waste they can sell these materials to the Recyclable Materials Recovery Enterprises and get paid for it. Of course, these payments do not increase workers' incomes. Therefore, it often happens that workers put aside part of the recyclable materials they collect and bring them privately and secretly to the payback centers where they get paid for them. That means that the performance of the communales in RM collection is also inefficient and unsatisfactory.

Therefore, we recommend that the communales give up the collection of RM completely and specialize in the collection and deposition of residual waste RW only. In this case, the professional collection of recyclable materials would be left to the private agents, i.e. the independent contractors and the Cooperatives, who have a strong economic interest in doing a good job since they make their incomes from RM collection. In order to increase the work effectiveness of the communales it would be necessary to pay higher wages to make the jobs more attractive for workers and to increase the performance bonuses (monetary or in-kind) in order to trigger extra efforts. As a complementary measure, the possibility to lay off workers if they show a low work performance should be introduced. Of course, a strict monitoring of workers' performance on the job would be necessary. The combination of higher wages and higher material incentives for better work on the one hand and the threat of losing one's job in case of a low work performance on the other should motivate the workers of the communales to increase their work efforts. These measures could be complemented by the introduction of non-material extrinsic rewards like honorary titles (e.g. "worker of the month") or by intrinsic incentives in the sense of building up an appropriate social identity of good garbage workers. For that, society as well as workers themselves should be made aware of the immense importance of their job for the health of society and environment and of the responsibility they bear. This might trigger a kind of "warm glow" feeling if they are doing a good job. If most of the workers of the communales can be "infected" with a higher work morale resulting from their awareness of the importance of their job something like a new "corporate spirit" or "corporate identity" of the communales might develop. This could also influence the social interaction between workers in the sense that those who are lazy and doing a sloppy job are reproached by the others because they violate the social norms of professional work behavior. Such a peer-based monitoring system would be desirable because it would make the monitoring of workers by their superiors more or less redundant, which implies reducing transaction cost and overcoming the principal-agent problems typically arising in this context.

Summing up, for the accomplishment of the first of the above-mentioned goals, i.e. an improvement of garbage collection, the communales should concentrate their efforts on the collection of RW only and leave the collection of recyclable materials to private institutions like the independent contractors and the Cooperatives, because, differently from the 
communales, for ICs and CRMRs it is in their own best material interest to do a good job. In order to increase the performance of their workers the communales should increase wages and performance bonuses while, at the same time, introducing the possibility to lay off lowperformers. Complementary non-material extrinsic and intrinsic incentives would be helpful. Similar combinations of extrinsic and intrinsic incentives might be effective also for the other waste-related government agencies like the Buyback Centers and the Recyclable Materials Recovery Enterprises.

The second goal of reforming the Cuban waste management system is an increase of the waste recycling rate. A precondition for reaching this goal is a sufficient rate of waste separation in the public as well as in the private sector. In the public sector, government-controlled firms and institutions are forced by law to separate their waste, so that the RW fraction of the waste can be picked up by the communales who are now specialized in this task only. The RM will be collected by the private Cooperatives who are spin-offs from former public firms, which have been privatized. Typically, they have a good technical equipment and, therefore, the possibility to recycle the RM they collect before selling it on the national market to production firms. A high recycling rate and a thorough RM collection are in their own economic interest. Together with an improved performance of the communales and a strict monitoring of the waste separation by the public firms this seems to ensure a successful waste collection and recycling system in the public sector.

For the overall success of the garbage collection and recycling system, the private sector, i.e. private households and small private enterprises, play an important role. From fig. 1 it can be seen that the decision problem of this sector regarding the handling of garbage consists of two stages. At the first stage, private agents have to decide on their personal waste separation rate. Households who do not separate their garbage at all can simply drop it into the garbage containers in their streets where it is picked up by the communales. This means no personal effort and no cost for them, but there is also no financial reward. If they separate their garbage, they have the possibility to sell the RM part directly to the Buyback Centers or to the ICs, which means that separation is rewarded financially. The low waste separation rate of private households shows that this reward is much too small to motivate private waste separation sufficiently. Therefore, stronger incentives for waste separation like higher compensation payments and better information on the national importance of waste separation and recycling would be helpful to create extrinsic as well as intrinsic motivation to comply with the goals of better waste management.

If households decide to separate (part of) their garbage, they have five different possibilities under the present system to forward the recyclable part of their garbage to the Recyclable Materials Recovery Enterprises, as is shown in fig. 1: They can bring their recyclable material directly to the Buyback Centers or they can leave it to the communales, the Independent Contractors for recyclable material collection, the Cooperatives for Recyclable Materials Recovery or the Young Pioneers or to the neighborhood committees for the Defense of the Revolution in the course of their waste collection campaigns. This variety of different possibilities makes the decision problem of the private sector rather confusing, as is shown in fig. 1, and the incentives accruing from the different possibilities are not clear. In order to make this decision problem of households clearer and more transparent we suggest, as already explained, that the communales do not deal with RM at all. Further, we recommend that the Cooperatives focus their activities on the collection and recycling of RM from the 
public sector, where the RM volume is much greater than in the private sector, and leave the private sector to the ICs. This reduces the complexity of the garbage decision problem in the private sector considerably, as is shown in fig. 3. Now households have the possibility to either bring their RM directly to the Buyback Centers and get paid for it or sell it to the ICs who pick up the RM at people's homes. The Buyback Centers pay higher prices for the RM but people have to bring the RM there themselves and they have to clean the materials (bottles, cans etc.) before. So the decision which of these two possibilities they choose will depend on the difference between the prices paid by the Buyback Centers and the ICs, where the prices paid by the Buyback Centers to households and private firms have to be adjusted for the opportunity cost of the time and effort invested in cleaning the RM and bringing it to the Buyback Centers. For private agents who have the possibility to earn additional money if they do some work instead of cleaning RM and bringing it to the Buyback Centers will prefer to sell their RM to the ICs instead of handling it themselves, while old and/or jobless people might possibly prefer to bring their cleaned RM to the Buyback Centers directly.

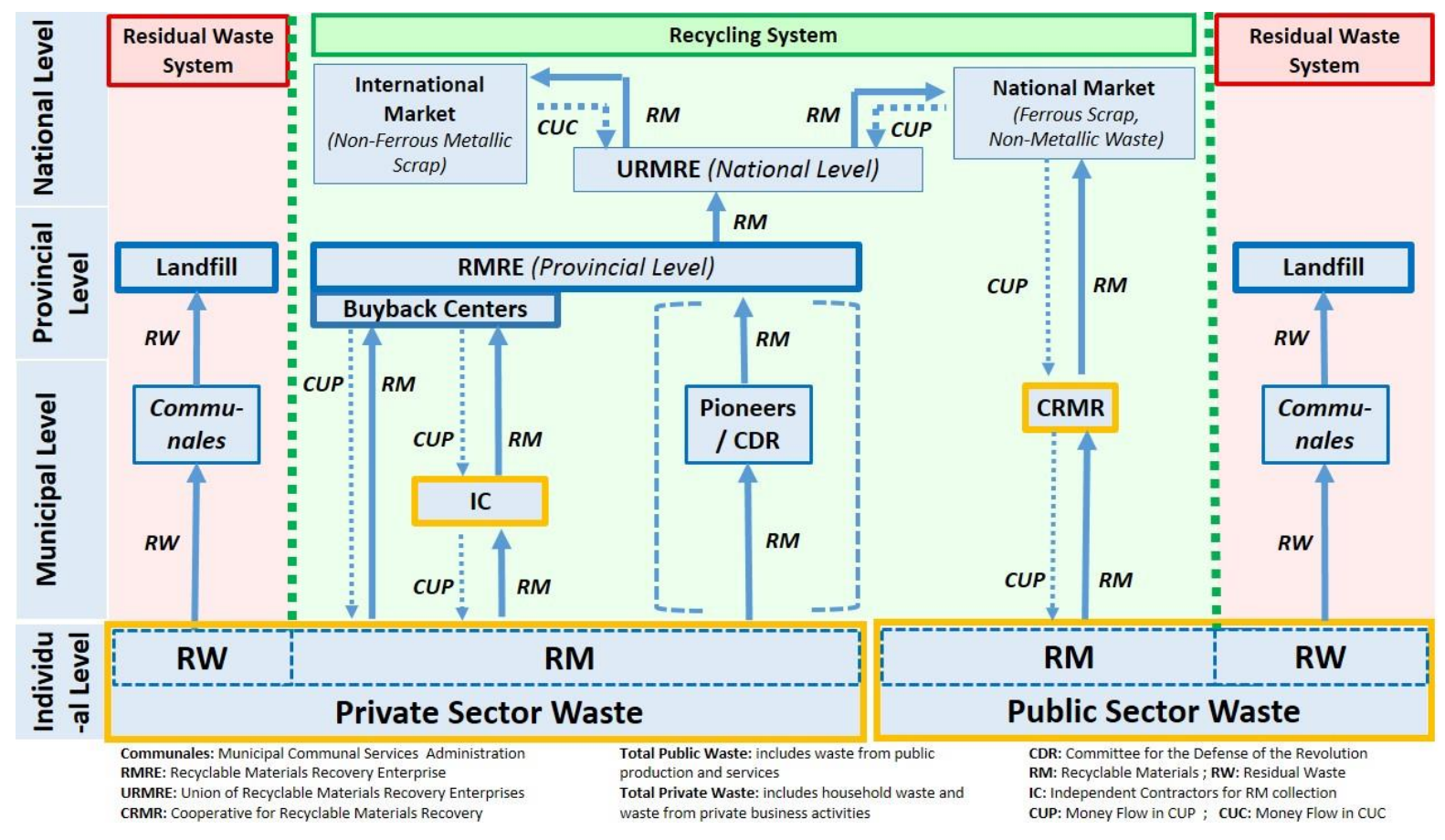

- Fig. 3: Simplified Waste Management System of Cuba -

In fig. 3 a third possibility of how to deal with RM in the private sector is shown in brackets. The Young Pioneers as well as the neighborhood committees (CDR) organize waste collection campaigns from time to time where they collect RM from private households or firms and bring it to the Buyback Centers. If households leave their RM to the Young Pioneers or to the neighborhood committees, they obtain no financial compensation. Nevertheless, supporting these campaigns increases one's reputation and social capital in the neighborhood so that there exist non-material incentives to participate in these campaigns, which are organized only at irregular time intervals, anyway. These immaterial incentives have to be traded off against the material incentives to give the RM to the Buyback Centers of the ICs. 


\section{Concluding remarks}

Even though the Cuban population is far from being an affluent consumer society, it faces severe problems with the waste it produces. If one abstracts from the threats arising from careless waste deposition in unsafe landfills there remain two important waste problems. One is the inefficient and unreliable garbage collection practice and the second is the insufficient waste recycling and resource recovery in Cuba. In this paper, we dealt with both problems from an empirical as well as a theoretical perspective.

In the empirical part, we presented the results of a small survey we conducted in the city of Havana. This survey showed that residents of Havana are well aware of the garbage collection problem and the resulting threats to human health and to the environment. It turned out that people find it important to implement a more effective and reliable waste management in Havana and that they would also be willing to contribute personally and financially to its realization. These results emphasize the relevance of the waste topic for the local people. In the theoretical part of our paper, we then analyzed the structure of the Cuban waste management system and tried to identify the sources of its deficiencies. It showed that besides the poor state of the technical equipment one of the main causes of the Cuban waste collection and recycling problem is the lack of cooperation of all parties concerned with waste management, i.e. private households, private and public enterprises and also the employees of the garbage collection firms. In spite of the urgency with which the respondents of our survey demanded a reform of the waste collection in Havana in order to get cleaner streets and a less health-threatening environment in practice nobody seems to care. Households do not separate their garbage and drop it, instead, unseparated into the containers in the streets or directly on the pavement if the containers are full. The waste workers pick up the containers infrequently and incompletely and do not care to clean up the streets if garbage has been dropped beside the containers. As one of the main reasons for this misbehavior we identified a lack of appropriate incentives for households as well as firms and their employees to strive for a better garbage situation and to act in a more responsible and more pro-social way. Another reason is the confusing and seemingly unstructured organization of the Cuban waste collection and recycling system, which contains many duplications of tasks so that in the end nobody feels responsible. Since a modernization of the technical equipment of the waste sector seems quite unrealistic considering the dramatic lack of capital in all sectors of the Cuban economy we suggested, instead, a fundamental reorganization of the waste management system with a clear structure of responsibilities and a transparent system of material as well as immaterial incentives to cooperate for all parties involved in that system. In this context, the implementation of immaterial incentives like appropriate social norms, which are followed (and also monitored) by citizens and waste workers seems to be especially important. A new pro-social spirit within the Cuban population, which involves also an appropriate handling of garbage, appears to be a promising way to improve the dismal garbage situation in Cuba. Other countries like e.g. Germany have had good experience with this inexpensive but highly effective instrument of government policy in the waste sector, which is highly recommended especially for countries with insufficient capital resources. 


\section{Literature}

Ahlheim, M., Börger, T., Frör, O. (2013), The effects of extrinsic incentives on respondent behaviour in contingent valuation studies, Journal of Environmental Economics and Policy $2(1), 45-70$

Akerlof, G. A. and Kranton, R. E. (2000), Economics and identity. The Quarterly Journal of Economics, 115(3), 715-753.

Alberty (2014), El rastro de la basura, Gramma $11^{\text {st }}$ December 2014, available at <http://www.granma.cu/cuba/2014-12-11/el-rastro-de-la-basura> [16 th August 2018].

Andreoni, J. (1989), Giving with impure altruism: Applications to charity and Ricardian equivalence. Journal of political Economy, 97(6), 1447-1458.

Andreoni, J. (1990), Impure altruism and donations to public goods: A theory of warm-glow giving. The economic journal, 100(401), 464-477.

Ariely, D., Bracha, A. and Meier, S. (2009), Doing Good or Doing Well? Image Motivation and Monetary Incentives in Behaving Prosocially. American Economic Review, 99(1), 544-555.

Arrow, K., Solow, R., Portney, P. R., Leamer, E. E., Radner, R. and Schuman, H. (1993), Report of the NOAA panel on contingent valuation. Federal register, 58(10), 4601-4614.

Atkinson, G. and Mourato, S. (2008), Environmental cost-benefit analysis. Annual review of environmental and resources, 33, 317-344.

Bateman, I., Carson, R. T., Day, B., Hanemann, M. Hanley, N., Hett, T., Jones-Lee, M., Loomes, G. Mourato, S. Özdemiroglu, E. Pearce, D. W., Sugden, R. and Swanson, J. (2002), Economic Valution with Stated Preference Techniques: a manual, Cheltenham: Elgar.

Bénabou, R. and Tirole, J. (2003), Intrinsic and extrinsic motivation. The review of economic studies, 70(3), 489-520.

Bénabou, R. and Tirole, J. (2006), Incentives and Prosocial Behavior. American Economic Review, 96(5), 1652-1678.

Bénabou, R. and Tirole, J. (2011), Identity, morals, and taboos: Beliefs as assets. The Quarterly Journal of Economics, 126(2), 805-855.

Carson, R.T. and Hanemann, W.M. (2005), Contingent Valuation, In: Handbook of Environmental Economics, Volume 2, Valuing Environmental Changes, Ed. by Maler, K.-G., Vincent, J. R., North-Holland: Elsevier.

Coleman, J. S. (1990), Foundations of social theory. Cambridge, MA.

Cubadebate (2013), Cuba apuesta al reciclaje, available at <http://www.cubadebate.cu/ \%20especiales/2013/06/27/cuba-apuesta-al-reciclaje/\#.W5JShcJCSpp > [17 $7^{\text {th }}$ August 2018].

Fehr, E. and Falk, A. (1999), Wage rigidity in a competitive incomplete contract market. Journal of political Economy, 107(1), 106-134.

Fehr, E. and Schmidt, K. M. (2000), Fairness, incentives, and contractual choices. European Economic Review, 44(4-6), 1057-1068.

Frey, B. S. (1994), How intrinsic motivation is crowded out and in. Rationality and society, 6(3), 334-352. 
Frey, B. S. and Jegen, R. (2001), Motivation crowding theory. Journal of economic surveys, 15(5), 589-611.

Gneezy, U., Meier, S. and Rey-Biel, P. (2011), When and why incentives (don't) work to modify behavior. Journal of Economic Perspectives, 25(4), 191-210.

Hobohm, J., Hahn, G. and Keggenhoff, I. (2017), Länderprofil zur Kreislauf- und Wasserwirtschaft in der Republik Kuba, Berlin: uve $\mathrm{GmbH}$ für Managementberatung.

Hong, S. M. and Faedda, S. (1996), Refinement of the Hong psychological reactance scale. Educational and Psychological Measurement, 56(1), 173-182.

Jank, J. (2018), Reciclaje: un camino necesario, Gramma $28^{\text {th }}$ June 2018, available at <http://www.granma.cu/economia-con-tinta/2018-06-28/reciclaje-un-camino-necesario28-06-2018-21-06-49> [24 ${ }^{\text {th }}$ August 2018].

Leary, M.R. and Kowalski, R.M. (1990), Impression Management: A Literature Review and Two-Component Model. Psychological Bulletin, 107(1), 34-47.

Lepper, M. R., Sagotsky, G., Dafoe, J. L. and Greene, D. (1982), Consequences of superfluous social constraints: Effects on young children's social inferences and subsequent intrinsic interest. Journal of Personality and Social Psychology, 42, 51-64.

Lloréns, M., Torres, M., Álvarez, H., Arrechea, A., García, J., Aguirre, S. and Fernández, A. (2008), Characterization of municipal solid waste from the main landfills of Havana city. Waste Management, 28, 2013-2021.

Lloréns, M., Torres, M., Arrechea, A., García, J. and Aguirre, S (2009), Cuban Research in Municipal Solid Waste. In: Solid Waste Management and Environmental Remediation. Ed. by Faerber, T., Herzog, J., New York: Nova Science Publishers Inc: 1-52.

Louro, A. (2013), Los servicios comunales y la higiene ambiental en la ciudad, Revista Cubana de Salud Pública, 39 (2) 402-405, La Habana.

Nunes, P. A. L. D. (2002), The contingent valuation of natural parks: assessing the warmglow propensity factor, Cheltenham: Elgar.

Osterloh, M. and Frey, B. S. (2000), Motivation, knowledge transfer, and organizational forms. Organization science, 11(5), 538-550.

Steindl, C., Jonas, E., Sittenthaler, S., Traut-Mattausch, E. and Greenberg, J. (2015), Understanding Psychological Reactance. Zeitschrift für Psychologie, 223(4), 205-2014.

Sunstein, C. and Thaler, R. (2008), Nudge. The politics of libertarian paternalism. New Haven.

Tamayo, J. L. (2017, March 30), Reciclaje de materias primas en Cuba, Mesa Redonda Program: Interview with Jorge Luis Tamayo, available at <https://www.youtube.com/ watch?v=HrxAobEZAAY $>\left[17^{\text {th }}\right.$ August 2018]. 
Appendix: Prices paid by the Buyback Centers for recyclable materials

\begin{tabular}{|c|c|c|}
\hline Product & Unit & Price \\
\hline \multicolumn{3}{|l|}{ Glass } \\
\hline Pharmacy bottles & U & 0.01 \\
\hline Medicine bottles from 15 to $240 \mathrm{ml}$ & $\mathrm{U}$ & 0.30 \\
\hline Glass container, $314 \mathrm{ml}$ & $U$ & 1.00 \\
\hline Glass container, $212 \mathrm{ml}$ & $\mathrm{U}$ & 1.00 \\
\hline Glass container, $997 \mathrm{ml}$ & $\mathrm{U}$ & 1.00 \\
\hline Glass container, $250 \mathrm{ml}$ & $U$ & 1.00 \\
\hline Bottles of Rum, $700 \mathrm{ml}$ & $\mathrm{U}$ & 2.50 \\
\hline Bottles of Rum, $750 \mathrm{ml}$ & $\mathrm{U}$ & 2.50 \\
\hline Bottles of Rum, $1000 \mathrm{ml}$ & $\mathrm{U}$ & 2.50 \\
\hline Bottles of wine and liquors & $\mathrm{U}$ & 0.02 \\
\hline Bottles of Bordolesa wines 700 and $750 \mathrm{ml}$ & $\mathrm{U}$ & 1.00 \\
\hline Bottles of beer and malt (amber), $350 \mathrm{ml}$ & $\mathrm{U}$ & 1.20 \\
\hline Bottles of beer (green), $350 \mathrm{ml}$ & $\mathrm{U}$ & 1.20 \\
\hline Bottles of imported malt, lightened, $250 \mathrm{ml}$ & $\mathrm{U}$ & 0.80 \\
\hline Bottles of imported malt and beer, lightened, $330 \mathrm{ml}$ & $\mathrm{U}$ & 0.60 \\
\hline $\begin{array}{l}\text { Heavy amber and green bottles of malt and beer, } 350 \mathrm{ml} \text {, national } \\
\text { production }\end{array}$ & $U$ & 0.60 \\
\hline \multicolumn{3}{|l|}{ Paper } \\
\hline Corrugated paper & $\mathrm{Kg}$ & 1.25 \\
\hline White paper with printing & $\mathrm{Kg}$ & 1.10 \\
\hline Ordinary paper & $\mathrm{Kg}$ & 0.80 \\
\hline Magazines and printed matter (gazette) & $\mathrm{Kg}$ & 1.50 \\
\hline \multicolumn{3}{|l|}{ Non-metallic (does not include glass containers) } \\
\hline Miscellaneous textile waste & $\mathrm{Kg}$ & 0.09 \\
\hline $\begin{array}{l}\text { Polyethylene B / D (LDPE): from bags of milk, yogurt, chocolatín. Clean and } \\
\text { dry. }\end{array}$ & $\mathrm{Kg}$ & 5.00 \\
\hline $\begin{array}{l}\text { Polyethylene A / D (HDPE), packaging of shampoo, conditioner, cream, } \\
\text { medicine, milk, yogurt, deodorant, air freshener and descaler and others } \\
\text { (without the ball) }\end{array}$ & $\mathrm{Kg}$ & 6.50 \\
\hline Polyethylene A / D (HDPE) of injection from tanks, buckets & $\mathrm{Kg}$ & 6.50 \\
\hline \multicolumn{3}{|l|}{ Polyethylene A / D (HDPE)of injection from boxes } \\
\hline $\begin{array}{l}\text { Polyethylene B / D (LDPE): tops of oil pommels, cereal containers, milk and } \\
\text { other flexible tops, containers with ID } 4 \text { and their acronyms }\end{array}$ & $\mathrm{Kg}$ & 5.00 \\
\hline $\begin{array}{l}\text { Polypropylene (PP): tops deodorant pommels and containers with } \\
\text { identification } 5 \text { and acronyms PP. }\end{array}$ & $\mathrm{Kg}$ & 5.00 \\
\hline Polystyrene (PS): plastic furniture, refrigerators, TV and air conditioners & $\mathrm{Kg}$ & 5.00 \\
\hline $\begin{array}{l}\text { Post-consumer PET plastic waste (water, soft drinks, cosmetics, medicine, } \\
\text { beverages and others) }\end{array}$ & $\mathrm{Kg}$ & 5.00 \\
\hline Post-consumer PET plastic waste (oil) & $\mathrm{Kg}$ & 5.00 \\
\hline \multicolumn{3}{|l|}{ Ferrous Metal Scrap } \\
\hline Scrap steel (h / 800x500x500) & $\mathrm{Kg}$ & 0.60 \\
\hline Scrap steel out of measure & $\mathrm{Kg}$ & 0.40 \\
\hline Cast iron scrap generated by the population & $\mathrm{Kg}$ & 0.20 \\
\hline
\end{tabular}




\begin{tabular}{|l|r|r|}
\hline Aluminum Scrap & & \\
\hline Scrap aluminum, tools and old lamps & $\mathrm{Kg}$ & 13.00 \\
\hline Aluminum profiles & $\mathrm{Kg}$ & 13.00 \\
\hline $\begin{array}{l}\text { Cast aluminum with not more than 2\% steel (includes pistons and } \\
\text { crankcase) }\end{array}$ & $\mathrm{Kg}$ & 13.00 \\
\hline Aluminum radiators with copper content & $\mathrm{Kg}$ & 8.00 \\
\hline Aluminum cans contained beer, soft drinks and other drinks & $\mathrm{Kg}$ & 8.00 \\
\hline Bronze Scrap & $\mathrm{Kg}$ & 13.00 \\
\hline Bronze pieces of different alloys & $\mathrm{Kg}$ & 12.00 \\
\hline Mixed brass pieces & $\mathrm{Kg}$ & 3.00 \\
\hline Bronze chip and shale & $\mathrm{Kg}$ & 10.00 \\
\hline Copper Scrap & & \\
\hline Copper for refine & $\mathrm{Kg}$ & 0.80 \\
\hline Lead Scrap & $\mathrm{Kg}$ & 0.70 \\
\hline Pure soft lead (pieces of lead) & $\mathrm{Kg}$ & 4.00 \\
\hline Storage battery with lead content & $\mathrm{Kg}$ & 6.00 \\
\hline Non-Ferrous Metal Scrap & \\
\hline Calamina Zamac or Cayuela, Zinc, Aluminum and other alloys & \\
\hline Stainless steel scrap of different alloys & \\
\hline
\end{tabular}

Source: http://www.degranma.co.cu/materia-prima/listado-de-productos [21 ${ }^{\text {st }}$ August 2018]. 


\section{Hohenheim Discussion Papers in Business, Economics and Social Sciences}

The Faculty of Business, Economics and Social Sciences continues since 2015 the established "FZID Discussion Paper Series" of the "Centre for Research on Innovation and Services (FZID)" under the name "Hohenheim Discussion Papers in Business, Economics and Social Sciences".

\section{Institutes}

$510 \quad$ Institute of Financial Management

520 Institute of Economics

530 Institute of Health Care \& Public Management

540 Institute of Communication Science

550 Institute of Law and Social Sciences

560 Institute of Economic and Business Education

570 Institute of Marketing \& Management

580 Institute of Interorganizational Management \& Performance

\section{Research Areas (since 2017)}

INEPA "Inequality and Economic Policy Analysis"

TKID "Transformation der Kommunikation - Integration und Desintegration"

NegoTrans "Negotiation Research - Transformation, Technology, Media and Costs"

INEF "Innovation, Entrepreneurship and Finance"

Download Hohenheim Discussion Papers in Business, Economics and Social Sciences

from our homepage: https://wiso.uni-hohenheim.de/papers

\begin{tabular}{|c|c|c|}
\hline No. & Author & Title \\
\hline 01-2015 & $\begin{array}{l}\text { Thomas Beissinger, } \\
\text { Philipp Baudy }\end{array}$ & $\begin{array}{l}\text { THE IMPACT OF TEMPORARY AGENCY WORK } \\
\text { ON TRADE UNION WAGE SETTING: } \\
\text { A Theoretical Analysis }\end{array}$ \\
\hline 02-2015 & Fabian Wahl & $\begin{array}{l}\text { PARTICIPATIVE POLITICAL INSTITUTIONS AND } \\
\text { CITY DEVELOPMENT 800-1800 }\end{array}$ \\
\hline 03-2015 & $\begin{array}{l}\text { Tommaso Proietti, } \\
\text { Martyna Marczak, } \\
\text { Gianluigi Mazzi }\end{array}$ & $\begin{array}{l}\text { EUROMIND-D: A DENSITY ESTIMATE OF } \\
\text { MONTHLY GROSS DOMESTIC PRODUCT FOR } \\
\text { THE EURO AREA }\end{array}$ \\
\hline 04-2015 & $\begin{array}{l}\text { Thomas Beissinger, } \\
\text { Nathalie Chusseau, } \\
\text { Joël Hellier }\end{array}$ & $\begin{array}{l}\text { OFFSHORING AND LABOUR MARKET REFORMS: } \\
\text { MODELLING THE GERMAN EXPERIENCE }\end{array}$ \\
\hline 05-2015 & $\begin{array}{l}\text { Matthias Mueller, } \\
\text { Kristina Bogner, } \\
\text { Tobias Buchmann, } \\
\text { Muhamed Kudic }\end{array}$ & $\begin{array}{l}\text { SIMULATING KNOWLEDGE DIFFUSION IN FOUR } \\
\text { STRUCTURALLY DISTINCT NETWORKS } \\
\text { - AN AGENT-BASED SIMULATION MODEL }\end{array}$ \\
\hline 06-2015 & $\begin{array}{l}\text { Martyna Marczak, } \\
\text { Thomas Beissinger }\end{array}$ & $\begin{array}{l}\text { BIDIRECTIONAL RELATIONSHIP BETWEEN } \\
\text { INVESTOR SENTIMENT AND EXCESS RETURNS: } \\
\text { NEW EVIDENCE FROM THE WAVELET PERSPECTIVE }\end{array}$ \\
\hline 07-2015 & $\begin{array}{l}\text { Peng Nie, } \\
\text { Galit Nimrod, } \\
\text { Alfonso Sousa-Poza }\end{array}$ & $\begin{array}{l}\text { INTERNET USE AND SUBJECTIVE WELL-BEING } \\
\text { IN CHINA }\end{array}$ \\
\hline
\end{tabular}

Inst 
No. Author

08-2015 Fabian Wahl

09-2015 Peng Nie, Alfonso Sousa-Poza

10-2015 Kristina Bogner

11-2015 Bogang Jun, Tai-Yoo Kim

12-2015 Volker Grossmann Aderonke Osikominu Marius Osterfeld

13-2015 Martyna Marczak Tommaso Proietti Stefano Grassi

14-2015 Carolina Castagnetti Luisa Rosti Marina Töpfer

15-2015 Alexander Opitz

01-2016 Michael Ahlheim, Jan Neidhardt

02-2016 Bogang Jun, Alexander Gerybadze, Tai-Yoo Kim

03-2016 Peng Nie, Alfonso Sousa-Poza

04-2016 Peter Spahn

05-2016 Vincent Dekker, Kristina Strohmaier, Nicole Bosch

06-2016 Philipp Baudy, Dario Cords
Title

Inst

THE LONG SHADOW OF HISTORY

ROMAN LEGACY AND ECONOMIC DEVELOPMENT

520

- EVIDENCE FROM THE GERMAN LIMES

COMMUTE TIME AND SUBJECTIVE WELL-BEING IN URBAN CHINA

530

THE EFFECT OF PROJECT FUNDING ON INNOVATIVE PERFORMANCE AN AGENT-BASED SIMULATION MODEL

520

A NEO-SCHUMPETERIAN PERSPECTIVE ON THE ANALYTICAL MACROECONOMIC FRAMEWORK: THE EXPANDED REPRODUCTION SYSTEM

520

ARE SOCIOCULTURAL FACTORS IMPORTANT FOR STUDYING A SCIENCE UNIVERSITY MAJOR?

520

A DATA-CLEANING AUGMENTED KALMAN FILTER FOR ROBUST ESTIMATION OF STATE SPACE MODELS

520

THE REVERSAL OF THE GENDER PAY GAP AMONG PUBLIC-CONTEST SELECTED YOUNG EMPLOYEES

520

DEMOCRATIC PROSPECTS IN IMPERIAL RUSSIA: THE REVOLUTION OF 1905 AND THE POLITICAL STOCK MARKET

NON-TRADING BEHAVIOUR IN CHOICE EXPERIMENTS

THE LEGACY OF FRIEDRICH LIST: THE EXPANSIVE REPRODUCTION SYSTEM AND THE KOREAN HISTORY OF INDUSTRIALIZATION

FOOD INSECURITY AMONG OLDER EUROPEANS: EVIDENCE FROM THE SURVEY OF HEALTH, AGEING, AND RETIREMENT IN EUROPE

POPULATION GROWTH, SAVING, INTEREST RATES AND STAGNATION. DISCUSSING THE EGGERTSSONMEHROTRA-MODEL

A DATA-DRIVEN PROCEDURE TO DETERMINE THE BUNCHING WINDOW - AN APPLICATION TO THE NETHERLANDS

DEREGULATION OF TEMPORARY AGENCY EMPLOYMENT IN A UNIONIZED ECONOMY: DOES THIS REALLY LEAD TO A SUBSTITUTION OF REGULAR EMPLOYMENT? 
No. Author Title

Inst

$\begin{array}{ll}\text { 07-2016 } & \text { Robin Jessen, } \\ & \text { Davud Rostam-Afschar } \\ & \text { Sebastian Schmitz }\end{array}$

08-2016 Peng Nie,

Alfonso Sousa-Poza, Jianhong Xue

09-2016 Bogang Jun, Seung Kyu-Yi, Tobias Buchmann, Matthias Müller

10-2016 Vladan Ivanovic, Vadim Kufenko, Boris Begovic Nenad Stanisic, Vincent Geloso

11-2016 David E. Bloom Michael Kuhn Klaus Prettner

12-2016 Franz X. Hof Klaus Prettner

13-2016 Jung-In Yeon Andreas Pyka Tai-Yoo Kim

14-2016 Benjamin Fuchs

15-2016 Seung-Kyu Yi Bogang Jun

16-2016 Gregor Pfeifer Fabian Wahl Martyna Marczak

17-2016 Malte Klein Andreas Sauer

18-2016 Klaus Prettner

19-2016 Klaus Prettner Andreas Schaefer

20-2016 Vadim Kufenko Klaus Prettner
HOW IMPORTANT IS PRECAUTIONARY LABOR SUPPLY?

520

FUEL FOR LIFE: DOMESTIC COOKING FUELS

530 AND WOMEN'S HEALTH IN RURAL CHINA

THE CO-EVOLUTION OF INNOVATION NETWORKS: COLLABORATION BETWEEN WEST AND EAST GERMANY FROM 1972 TO 2014

CONTINUITY UNDER A DIFFERENT NAME. 520 THE OUTCOME OF PRIVATISATION IN SERBIA

THE CONTRIBUTION OF FEMALE HEALTH TO ECONOMIC DEVELOPMENT

THE QUEST FOR STATUS AND R\&D-BASED GROWTH

STRUCTURAL SHIFT AND INCREASING VARIETY IN KOREA, 1960-2010: EMPIRICAL EVIDENCE OF THE ECONOMIC DEVELOPMENT MODEL BY THE CREATION OF NEW SECTORS

THE EFFECT OF TEENAGE EMPLOYMENT ON CHARACTER SKILLS, EXPECTATIONS AND OCCUPATIONAL CHOICE STRATEGIES

HAS THE GERMAN REUNIFICATION

STRENGTHENED GERMANY'S NATIONAL INNOVATION SYSTEM? TRIPLE HELIX DYNAMICS OF GERMANY'S INNOVATION SYSTEM

ILLUMINATING THE WORLD CUP EFFECT: NIGHT LIGHTS EVIDENCE FROM SOUTH AFRICA

520

CELEBRATING 30 YEARS OF INNOVATION

570 SYSTEM RESEARCH: WHAT YOU NEED TO KNOW ABOUT INNOVATION SYSTEMS

THE IMPLICATIONS OF AUTOMATION FOR ECONOMIC GROWTH AND THE LABOR SHARE

HIGHER EDUCATION AND THE FALL AND RISE OF INEQUALITY

YOU CAN'T ALWAYS GET WHAT YOU WANT? ESTIMATOR CHOICE AND THE SPEED OF CONVERGENCE 
No. Author

01-2017 Annarita Baldanzi Alberto Bucci Klaus Prettner

02-2017 Julius Tennert Marie Lambert Hans-Peter Burghof

03-2017 Michael Ahlheim Oliver Frör Nguyen Minh Duc Antonia Rehl Ute Siepmann Pham Van Dinh

04-2017 Bohdan Kukharskyy Sebastian Seiffert

05-2017 Ana Abeliansky Klaus Prettner

06-2017 Vincent Geloso Vadim Kufenko

07-2017 Emanuel Gasteiger Klaus Prettner

08-2017 Klaus Prettner Holger Strulik

09-2017 David E. Bloom Simiao Chen Michael Kuhn Mark E. McGovern Les Oxley Klaus Prettner

10-2017 Sebastian Till Braun Nadja Dwenger

11-2017 Vadim Kufenko Klaus Prettner Vincent Geloso

12-2017 Frank M. Fossen Ray Rees Davud Rostam-Afschar Viktor Steiner

13-2017 Steffen Otterbach Michael Rogan

14-2017 Carolina Castagnetti Luisa Rosti Marina Töpfer
Title

Inst

CHILDRENS HEALTH, HUMAN CAPITAL

INEPA ACCUMULATION, AND R\&D-BASED ECONOMIC GROWTH

MORAL HAZARD IN VC-FINANCE: MORE EXPENSIVE THAN YOU THOUGHT

INEF

LABOUR AS A UTILITY MEASURE

520 RECONSIDERED

GUN VIOLENCE IN THE U.S.: CORRELATES AND

520 CAUSES

AUTOMATION AND DEMOGRAPHIC CHANGE

520

INEQUALITY AND GUARD LABOR, OR PROHIBITION AND GUARD LABOR?

INEPA

ON THE POSSIBILITY OF AUTOMATION-INDUCED

520 STAGNATION

THE LOST RACE AGAINST THE MACHINE:

INEPA AUTOMATION, EDUCATION, AND INEQUALITY IN AN R\&D-BASED GROWTH MODEL

THE ECONOMIC BURDEN OF CHRONIC

520 DISEASES: ESTIMATES AND PROJECTIONS FOR CHINA, JAPAN, AND SOUTH KOREA

THE LOCAL ENVIRONMENT SHAPES REFUGEE INTEGRATION: EVIDENCE FROM POST-WAR GERMANY

DIVERGENCE, CONVERGENCE, AND THE HISTORY-AUGMENTED SOLOW MODEL

HOW DO ENTREPRENEURIAL PORTFOLIOS RESPOND TO INCOME TAXATION?

INEPA

INEPA

SPATIAL DIFFERENCES IN STUNTING AND INEPA HOUSEHOLD AGRICULTURAL PRODUCTION IN SOUTH AFRICA: (RE-) EXAMINING THE LINKS USING NATIONAL PANEL SURVEY DATA

THE CONVERGENCE OF THE GENDER PAY GAP - AN ALTERNATIVE ESTIMATION APPROACH 
No. Author

$15-2017$

Andreas Hecht

16-2017 Mareike Schoop

D. Marc Kilgour (Editors)

17-2017 Mareike Schoop

D. Marc Kilgour (Editors)

18-2017 Sibylle Lehmann-Hasemeyer Fabian Wahl

19-2017 Stephanie Glaser

20-2017 Dario Cords

21-2017 Micha Kaiser

Jan M. Bauer

22-2017 Thilo R. Huning

Fabian Wahl

23-2017 Matthias Busse

Ceren Erdogan

Henning Mühlen

24-2017 Sibylle Lehmann-Hasemeyer Alexander Opitz

25-2017 Samuel Mburu

Micha Kaiser

Alfonso Sousa-Poza

26-2017 Marina Töpfer

27-2017 Robin Jessen

Maria Metzing

Davud Rostam-Afschar

28-2017 Alexander Kressner Katja Schimmelpfeng

29-2017 Clemens Lankisch

Klaus Prettner

Alexia Prskawetz
Title

Inst

ON THE DETERMINANTS OF SPECULATION - A 510

CASE FOR EXTENDED DISCLOSURES IN CORPORATE RISK MANAGEMENT

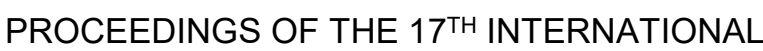
CONFERENCE ON GROUP DECISION AND

NegoTrans NEGOTIATION

DOCTORAL CONSORTIUM OF THE 17 TH INTERNATIONAL CONFERENCE ON GROUP DECISION AND NEGOTIATION

SAVING BANKS AND THE INDUSTRIAL REVOLUTION IN PRUSSIA

SUPPORTING REGIONAL DEVELOPMENT WITH PUBLIC FINANCIAL INSTITUTIONS

A REVIEW OF SPATIAL ECONOMETRIC MODELS FOR COUNT DATA

ENDOGENOUS TECHNOLOGY, MATCHING, AND

LABOUR UNIONS: DOES LOW-SKILLED IMMIGRATION AFFECT THE TECHNOLOGICAL ALIGNMENT OF THE HOST COUNTRY?

PRESCHOOL CHILD CARE AND CHILD WELLBEING IN GERMANY: DOES THE MIGRANT EXPERIENCE DIFFER?

LORD OF THE LEMONS: ORIGIN AND DYNAMICS OF STATE CAPACITY

STRUCTURAL TRANSFORMATION AND ITS RELEVANCE FOR ECONOMIC GROWTH IN SUBSHARAN AFRICA

THE VALUE OF POLITICAL CONNECTIONS IN THE FIRST GERMAN DEMOCRACY - EVIDENCE FROM THE BERLIN STOCK EXCHANGE

LIFESTOCK ASSET DYNAMICS AMONG
PASTORALISTS IN NORTHERN KENYA

INEPA

DETAILED RIF DECOMPOSITION WITH SELECTION - THE GENDER PAY GAP IN ITALY

INEPA

OPTIMAL TAXATION UNDER DIFFERENT CONCEPTS OF JUSTNESS

INEPA

CLUSTERING SURGICAL PROCEDURES FOR

580 MASTER SURGICAL SCHEDULING

ROBOTS AND THE SKILL PREMIUM: AN AUTOMATION-BASED EXPLANATION OF WAGE INEPA INEQUALITY 
No.

30-2017 Ann-Sophie Adelhelm Melanie Bathelt Mirjam Bathelt Bettina Bürkin Sascha Klein Sabrina Straub Lea Wagner Fabienne Walz

31-2017 Annarita Baldanzi Klaus Prettner Paul Tscheuschner

32-2017 Vincent Dekker Kristina Strohmaier

01-2018 Michael D. Howard Johannes Kolb

02-2018 Peter Spahn

03-2018 Aderonke Osikominu Gregor Pfeifer

04-2018 Theresa GrafenederWeissteiner Klaus Prettner Jens Südekum

05-2018 Vadim Kufenko Vincent Geloso Klaus Prettner

06-2018 Michael Trost

07-2018 Karsten Schweikert

08-2018 Evanthia Fasoula Karsten Schweikert

09-2018 Michael Ahlheim Jan Neidhardt Ute Siepmann Xiaomin $\mathrm{Yu}$
ARBEITSWELT: DIGITAL - BELASTUNG: REAL? 550 DER ERLEBTE WANDEL DER ARBEITSWELT INNERHALB DER IT-BRANCHE AUS SICHT DER ARBEITNEHMER

LONGEVITY-INDUCED VERICAL INNOVATION

AND THE TRADEOFF BETWEEN LIFE AND GROWTH

THE EFFECT OF TRANSFER PRICING

520

REGULATIONS ON INTRA-INDUSTRY TRADE

FOUNDER CEOS AND NEW VENTURE MEDIA

INEF COVERAGE

UNCONVENTIONAL VIEWS ON INFLATION 520 CONTRAOL: FORWARD GUIDANCE, THE NEOFISHERIAN APPROACH, AND THE FISCAL THEORY OF THE PRICE LEVEL

PERCEIVED WAGES AND THE GENDER GAP IN STEM FIELDS

THREE PILLARS OF URBANIZATION: MIGRATION, INEPA AGING, AND GROWTH

DOES SIZE MATTER? IMPLICATIONS OF INEPA HOUSEHOLD SIZE FOR ECONOMIC GROWTH AND CONVERGENCE

THE WHOLE IS GREATER THAN THE SUM OF ITS 520 PARTS - PRICING PRESSURE INDICES FOR MERGERS OF VERTICALLY INTEGRATED FIRMS

TESTING FOR COINTEGRATION WITH TRESHOLD ADJUSTMENT IN THE PRESENCE OF STRUCTURAL BREAKS

PRICE REGULATIONS AND PRICE ADJUSTMENT DYNAMICS: EVIDENCE FROM THE AUSTRIAN RETAIL FUEL MARKET

WECHAT - USING SOCIAL MEDIA FOR THE ASSESSMENT OF TOURIST PREFERENCES FOR 520 ENVIRONMENTAL IMPROVEMENTS IN CHINA 
No.

10-2018 Alexander Gerybadze Simone Wiesenauer

11-2018 Klaus Prettner Niels Geiger Johannes Schwarzer

12-2018 Martyna Marczak Thomas Beissinger

13-2018 Niels Geiger Klaus Prettner Johannes Schwarzer

14-2018 Klaus Prettner Sebastian Seiffert

15-2018 Marina Töpfer

16-2018 Timo Walter

17-2018 Jonas Frank

18-2018 Jonas Frank

19-2018 Dario Cords Klaus Prettner

20-2018 Sibylle Lehmann-Hasemeyer Andreas Neumayer

21-2018 Nadja Dwenger Lukas Treber

22-2018 Octavio Escobar Henning Mühlen

23-2018 Davud Rostam-Afschar Kristina Strohmaier
Title

Inst

THE INTERNATIONAL SALES ACCELERATOR: A

570

PROJECT MANAGEMENT TOOL FOR IMPROVING SALES PERFORMANCE IN FOREIGN TARGET MARKETS

DIE WIRTSCHAFTLICHEN FOLGEN DER AUTOMATISIERUNG

INEPA

COMPETITIVENESS AT THE COUNTRY-SECTOR LEVEL: NEW MEASURES BASED ON GLOBAL VALUE CHAINS

AUTOMATISIERUNG, WACHSTUM UND UNGLEICHHEIT

INEPA

THE SIZE OF THE MIDDLE CLASS AND

INEPA EDUCATIONAL OUTCOMES: THEORY AND EVIDENCE FROM THE INDIAN SUBCONTINENT

THE EFFECT OF WOMEN DIRECTORS ON INNOVATION ACTIVITY AND PERFORMANCE OF CORPORATE FIRMS

- EVIDENCE FROM CHINA -

TRADE AND WELFARE EFFECTS OF A POTENTIAL FREE TRADE AGREEMENT BETWEEN JAPAN AND THE UNITED STATES

THE EFFECTS OF ECONOMIC SANCTIONS ON TRADE: NEW EVIDENCE FROM A PANEL PPML GRAVITY APPROACH

THE EFFECT OF CULTURE ON TRADE OVER TIME - NEW EVIDENCE FROM THE GLOBE DATA SET

TECHNOLOGICAL UNEMPLOYMENT REVISITED: INEPA AUTOMATION IN A SEARCH AND MATCHING FRAMEWORK

THE PERSISTENCE OF OWNERSHIP INEQUALITY INEPA - INVESTORS ON THE GERMAN STOCK EXCHANGES, 1869-1945

SHAMING FOR TAX ENFORCEMENT: EVIDENCE FROM A NEW POLICY

THE ROLE OF FDI IN STRUCTURAL CHANGE: EVIDENCE FROM MEXICO

DOES REGULATION TRADE-OFF QUALITY AGAINST INEQUALITY? THE CASE OF GERMAN ARCHITECTS AND CONSTRUCTION ENGINEERS
520

520

INEPA 
No.

24-2018

Peng Nie

Lanlin Ding

Alfonso Sousa-Poza

25-2018 Michael Ahlheim

Maike Becker

Yeniley Allegue Losada

Heike Trast
Title

Inst

OBESITY INEQUALITY AND THE CHANGING

INEPA SHAPE OF THE BODYWEIGHT DISTRIBUTION IN CHINA

WASTED! RESOURCE RECOVERY AND WASTE MANAGEMENT IN CUBA
520 


\section{IMPRINT}

University of Hohenheim

Dean's Office of the Faculty of Business, Economics and Social Sciences Palace Hohenheim $1 \mathrm{~B}$ 70593 Stuttgart | Germany Fon $+49(0) 71145922488$ Fax +49 (0)71145922785 wiso@uni-hohenheim.de wiso.uni-hohenheim.de 